\title{
Antibody-drug Conjugate SC-004
}

National Cancer Institute

\section{Source}

National Cancer Institute. Antibody-drug Conjugate SC-004. NCI Thesaurus. Code C136807.

An antibody-drug conjug ate (ADC) composed of a proprietary monoclonal antibody against a tumor-associated antigen (TAA) linked to a currently undisclosed cytotoxic agent, with potential antineoplastic activity. Upon intravenous administration, the monoclonal antibody moiety of SC-004 targets and binds to the TAA expressed on tumor cells. Upon binding and internalization, the cytotoxic agent is released and kills the TAA-expressing cancer cells, through an unknown mechanism of action. 